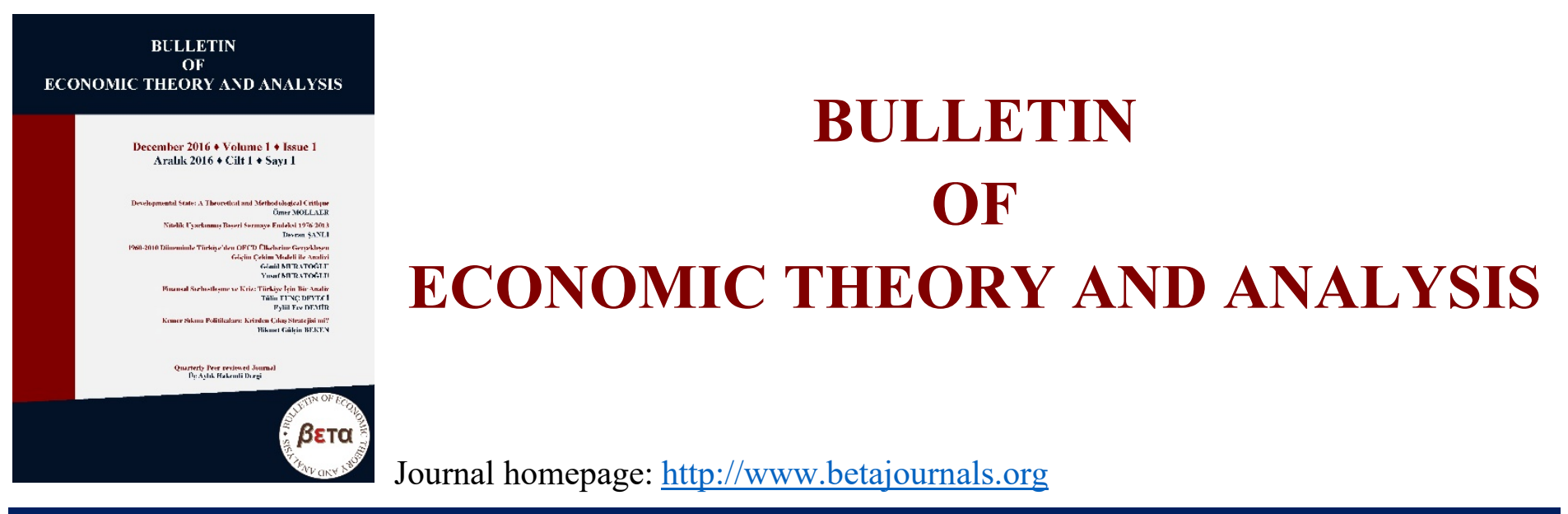

\title{
Denetimin Değişen Yüzü; Geleceğin Denetçisi
}

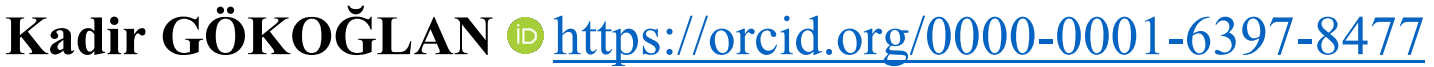

\section{İbrahim ÇEMBERLITAŞ ๑ https://orcid.org/0000-0002-2489-9060}

To cite this article: Gökoğlan, K. \& Çemberlitaş, İ. (2021). Denetimin Değişen Yüzü; Geleceğin Denetçisi. Bulletin of Economic Theory and Analysis, 6(2), 115-129.

Received: 26 Nov 2021

Accepted: 09 Dec 2021

Published online: 31 Dec 2021

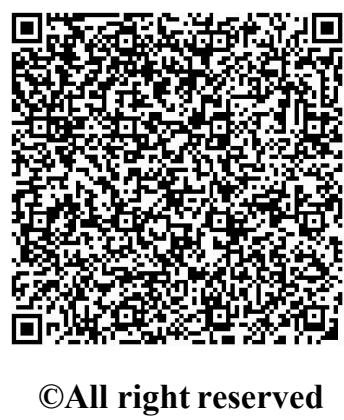




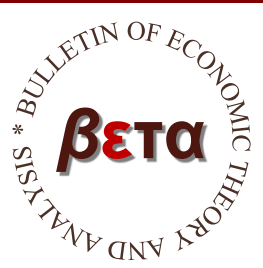

\title{
Bulletin of Economic Theory and Analysis
}

\author{
Volume VI, Issue 2, pp. 115-129, 2021 \\ http://www.betajournals.org
}

\author{
Original Article / Araştırma Makalesi \\ Received / Alınma: 26.11.2021 Accepted / Kabul: 09.12.2021
}

\section{Denetimin Değișen Yüzü; Geleceğin Denetçisi}

\author{
Kadir GÖKOĞLAN ${ }^{\mathrm{a}}$ \\ İbrahim ÇEMBERLITAŞ ${ }^{b}$
}

ä̈ğr. Gör. Dr., Dicle Üniversitesi Diyarbakır Sosyal Bilimler Meslek Yüksek Okulu, Muhasebe ve Vergi Bölümü, Diyarbakır, TÜRKIYE @ https://orcid.org/0000-0001-6397-8477

${ }^{b}$ Dr. Öğr. Üyesi, Van Yüzüncü Yıl Üniversitesi, İktisadi ve İdari Bilimler Fakültesi, İşletme Bölümü, Van, TÜRKIYE $@$ https://orcid.org/0000-0002-2489-9060

\section{ÖZ}

Değişen finansal olaylar ve bilgi teknolojileri çerçevesinde denetim faaliyetlerinin de bu değişime ayak uydurması zorunlu hale gelmiştir. Dolayısıyla denetim faaliyetini gerçekleştiren denetçilerin mesleki bilgi ve becerilerini değişime ayak uydurabilecek şekilde revize etmesi gerekmektedir. Denetim günümüzde kritik bir noktadadır. Özellikle, faaliyetlerin gerçekleştirilmesinde gerçek zamanlı yaklaşımlarla birlikte bilgi teknolojisindeki gelişmeler denetim mesleğinin revize edilmesini gerektirmektedir.

$\mathrm{Bu}$ çalışma işletmelerde denetim faaliyetlerinden sorumlu denetim yöneticisi veya sorumlusunun gelecekteki vizyonunun belirlenmesi ve işletme bilgi kullanıcılarına sağlıklı ve doğru bilgilerin sağlanmasında denetçilerin değişen rolünü belirtmek amacıyla gerçekleştirilmiştir. Geleceğin denetçisi olarak adlandırılan denetim ile ilgili meslek mensuplarının değişen ve gelişen dünyada işlemelere sağlayacağı artı katma değerin belirlenmesi ön planda tutulmuştur. Dolayısıyla geleceğin denetçisinin misyon ve vizyonu yeniden belirlenmiştir.

Anahtar Kelimeler

Muhasebe

Denetimi, Denetçi, Geleceğin Denetçisi

\section{JEL Kodu}

M42

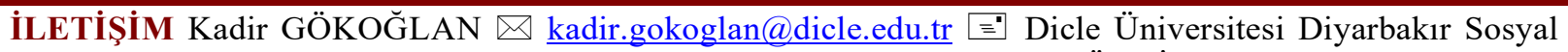
Bilimler Meslek Yüksek Okulu, Muhasebe ve Vergi Bölümü, Diyarbakır, TÜRKIYYE 


\title{
The Changing Face of Audit; The Auditor of the Future
}

\begin{abstract}
Within the framework of changing financial events and information technologies, audit activities have become mandatory to keep pace with this change. Therefore, the auditors who carry out the audit activity should revise their professional knowledge and skills in a way that can keep pace with the change. Auditing is at a critical point today. In particular, developments in information technology, together with real-time approaches to the realization of activities, require a revision of the audit profession.

This study was carried out in order to determine the future vision of the audit manager or supervisor responsible for audit activities in enterprises and to indicate the changing role of auditors in providing healthy and accurate information to business information users. As the auditor of the future, the determination of the added value that audit-related professionals will provide to transactions in a changing and developing world has been given priority. Therefore, the mission and vision of the auditor of the future has been redetermined.
\end{abstract}

\section{Keywords}

Accounting Audit,

Auditor,

Auditor of the

Future

JEL Classification M42

\section{Giriş}

Denetim kavramı Latince kökenli bir kelime olup işitme, dinleme kelimelerine karşılık gelmektedir. Bunların anlamı da denetlenecek olan işlerin işitmek veya dinlemek suretiyle yapılıyor olması anlamı taşımaktaydı. Farklı zamanlarda bir takım evreler geçirmiş olan denetim kavramı Türkçe 'ye çevrildiğinde ise muhasebe denetimi olarak çevrilmiştir. İşletmelere ait bilgilerin, finansal tabloların denetim işlemlerinin muhasebe denetiminin ilgi alanı olması da bu kavramın Türkçe 'ye muhasebe denetimi olarak çevrilmesinde etkili olduğu düşünülmektedir.

Denetim, bir anlamda muhasebe dünyasının bir parçası olarak düşünüldüğünde yapılan muhasebe kayıtlarının ve düzenlenen finansal tabloların incelenmesinin denetimin bir fonksiyonu olduğu anlaşılmaktadır. Daha doğru bir ifade ile yapılan bu işlemlerin yasalara ve genel kabul görmüş muhasebe ilkelerine uygun düzenlenip düzenlenmediğinin denetlenmesi işlemi olduğu anlaşılmaktadır. Dolayısıyla muhasebecinin işlemlerinin bittiği yerde denetim işinin başladığı söylenebilir.

Denetim görevini yerine getiren denetçilerin bağımsız davranabilmesi işletmelerin finansal tablolarının şeffaf olmasını ciddi derecede etkilemektedir. Dolayısıyla denetçi denetim faaliyetlerine başlamasından bitirmesine kadar mesleki tecrübesine dayanarak işlerini yürütmelidir ve herhangi bir baskı altında ise işini devam ettirmemesi gerekmektedir. 
İşletmenin şeffaflığında en önemli unsurlardan biri, işletmeye karşı bağımsız davranması gereken denetçinin rolüdür. $\mathrm{Bu}$ aynı zamanda işletmenin sürdürülebilirliğinin de sağlanması anlamına gelmektedir (Saxunova, 2017: 45).

\section{Denetim Kavramı}

Bir ekonomik birimin ya da işletmenin belirli bir döneme ait bilgilerinin belirlenmiş olan standartlara veya ölçütlere uygunluğunun araştırılması muhasebe denetiminin tanımıdır. Bununla beraber yapılan araştırmanın standartlara uygunluğu ile ilgili raporların oluşturulabilmesi için uzmanlarca kanıtların toplanması ve değerlendirilmesi süreci de tanımda yer alan diğer unsurlardır (Bozkurt, 2015: 29). Bu anlamda denetim, işletme ilgili olduğu iddia edilen bilgileri doğru ve eksiksiz olarak yansıtıp yansıtmadıklarını belirlemek amacıyla yapılan muhasebe kayıtlarının incelenmesidir (Dickey, akt., Franklin, 2017: 1). Denetim, denetçinin işletme ile ilgili bir rapor hazırlamasını sağlamak için belirli kanıtların incelenmesini içeren bazı rakam ifadelerinin araştırılması olarak tanımlanmaktadır (Perry, akt., Franklin, 2017: 1).

Denetim, ortaklar veya hissedarlar gibi yönetimle ilişkili olmayan kişilerin mali çıkarlarını güvence altına alır, çalışanlar üzerinde ahlaki bir denetim görevi görür ve sahtekârlık yapmalarını önlemektedir (ICSI, 2014: 320).

Denetimin işlevinin finansal tablolara güvenilirlik kazandırmak olduğu söylenebilir. Finansal tabloların şeffaflığı denetçinin sorumluluğundadır ve bu anlamda denetçinin bir görevi de işletme yöneticilerine finansal tablolar konusunda güvenilirlik kazandırmaktır. Denetim sürecinde denetçi, finansal tabloların kullanışlılığını ve değerini artırır (Hayes, Dassen, Schilder, \& Wallage, 2005: 3)

Denetim faaliyeti içerisinde birkaç adımı barındıran bir süreçtir. Denetim firması denetlenmeyi talep eden işletmelerden gelen davet üzerine denetim faaliyetlerine başlamaktadır.

Denetim sürecinin başlaması müşteri işletmeden denetim talebinin gelmesiyle başlamaktadır. Sürecin devamında denetim planı yapılır ve uygulanır. Son aşamada da denetim raporu hazırlanarak denetim süreci bitirilmektedir (Öztürkçü A. \& Bilen, 2018: 241).

Muhasebe denetiminin sağlayacağı yararları aşağıdaki gibi sıralamak mümkündür (ICSI, 2014: 325):

$\checkmark$ Mal sahibinin memnuniyeti, 
$\checkmark$ Hata ve sahtekârlıkların tespiti ve önlenmesi,

$\checkmark$ Kitapların doğrulanması,

$\checkmark$ Bağımsız görüş,

$\checkmark$ Ahlaki kontrol,

$\checkmark$ Pay sahiplerinin hak ve menfaatlerinin korunması,

$\checkmark$ Yabancilar tarafından güven,

$\checkmark$ Yasal gerekliliklere uygunluğu sağlar,

$\checkmark$ İç kontrolü güçlendirin ve güçlendirin,

$\checkmark$ Kredi tesisi.

Denetim faaliyetlerinin çeşitli aşamalardan geçerek bitirilmesiyle işletmelerde finansal tablolara olan güvenin artması sağlanacaktır. Bu güven de denetim kalitesinin ne kadar iyi olduğu ile ilgilidir. Denetçi kendisinde bulunması gereken özellikleri faaliyetlerine aktarırken önceden belirlenen denetim standartlarına uyum ile birleştirmesi sonucu denetim faaliyeti kaliteli hale gelmektedir. Denetimin kaliteli hale gelmesi de işletme finansal tablo kullanıcılarının işletmeye ve denetime olan güvenini arttırdığı ifade edilebilir.

Denetimde kalitenin sağlanması denetlenen işletme açısından oldukça önem teşkil etmektedir. Kaliteyi etkileyen bazı unsurlar bulunmaktadır ve bu unsurların kesinlikle göz ardı edilmemesi gerekmektedir. Denetimi yapan firma ile denetlenen işletmenin bir birlerinden bağımsız olmaları bu faktörlerin başında gelmektedir. Zira bağımsız denetçinin yüksek mesleki bağımsızlığının olması ve tarafsız davranabilmesinin güzel bir sonucu olacak denetim işlemi kaliteli bir şekilde sonuçlanabilmektedir (Hatunoğlu \& Koca, 2020: 1120).

\section{Denetçi}

Denetimin tanımında söz edilen faaliyetleri, mesleki bilgisine ve deneyimlere dayanarak yerine getiren ve yüksek ahlaki nitelikler taşıyan uzman kişilere denetçi denir. Denetim faaliyetlerini yürüten denetçiler herhangi bir baskı altında kalmadan ve hür iredeleri ile denetimlerini yapmak durumundadırlar.

Denetçiler denetim faaliyetlerini yürütürken önemli olarak nitelendirilen bazı niteliklere haiz olmalıdır. Bu nitelikler şunlardır (Bozkurt, 2015: 37):

$\checkmark$ Denetçiler, yeterli mesleki bilgi ve tecrübeye sahip olmalıdır

$\checkmark$ Denetçiler, denetim faaliyetlerinde bağımsız davranabilmelidirler 
$\checkmark$ Denetçiler, çalışmalarını özenle sürdürmelidirler

$\checkmark$ Denetçiler, kişilikli ve ahlaklı bireyler olmalıdırlar

Denetim kavramının tanımında yer alan ayrıntılar sebebiyle denetim tanımı farklı kriterlere göre ayrı ayrı tanımlanmıştır. Bu ayrımlara bakıldığında denetim kavramı aşağıdaki gruplara göre tanımlanmaktadır (Tez, 2021: 115):

$\checkmark$ Amaçlarına göre denetim; finansal tabloların denetimi, uygunluk denetimi ve faaliyet denetimi

$\checkmark$ Denetçinin statüsüne göre denetim; kamu denetimi, iç denetim ve bağımsız denetim

$\checkmark$ Sürekli-sınırlı denetim

Denetçi raporu denetim sürecindeki son adımdır. Denetimin nihai ürünü olarak denetçi raporu, denetçinin denetim sürecinin bulgularını kamuoyu ile iletişim kurmasının bir yoludur (Aqel, 2014: 5).

Denetçilik mesleğinin profesyonel hale gelmesinde denetçilerin sorumluluklarının kanunlarla belirlenmesi, işletme ilgililerinin ve müşteri işletme çıkarlarının korunması ve denetçilerin hangi alanlarda bağımsız bir şekilde nasıl çalışmaları gerektiği ve çalışmalarından nasıl sorumlu olacaklarının belirlenmesinin önemi göz ardı edilmeyecek bir gerçektir (Akyüz \& Kestane, 2020: 192).

Bağımsız denetçi, işletmelerin finansal tablolarında yer alan bilgilerin kabul görmüş muhasebe ilke ve temel kavramlar çerçevesinde oluşturulup oluşturulmadığı ve bu bilgilerin güvenilir olup olmadığı konusunda bir görüşü temsil etmektedir (Gökoğlan, 2021: 66). Bağımsız denetçi ile iç denetçinin birlikte hareket ederek kontrolleri koordine bir şekilde yapmaları raporlamalardaki olası hilelerin daha fazla ortaya çıkarılması sağlanacaktır. Böylelikle işletme içi ve işletme dışı kullanıcıların daha sağlıklı bilgilere ulaşmaları sağlanacaktır. Dolayısıyla koordineli hareket etmenin sonucu olarak hataların nelerden kaynaklandığı, nasıl düzeltilmesi gerektiği ve ilgililere doğru işlemin nasıl öğretileceği gibi faydalı sonuçlar ortaya çıkacaktır (Demir, Ülker, \& Arslan, 2018: 100).

\section{Bağımsız Denetim}

Herhangi bir işletmenin bir yıl içindeki faaliyetlerini gösteren mali tablolarının ve diğer finansal bilgilerinin belirlenmiş standart ve kriterlere uygunluğunun bağımsız bir denetçi tarafından denetlenmesi bir bağımsız denetim faaliyetidir. Bağımsız denetim faaliyetlerinde 
kritlere uygun denetim kanıtları elde edilmeye çalışılmaktadır. Bağımsız denetim faaliyetleri müşteri işletmenin kabulü ile başlayan ve nihai görüşün bildirildiği denetim raporunun oluşturulması ile son bulmaktadır (Gökoğlan, 2021:67).

Denetimin tanımı yapılırken üzerinde durulan birkaç önemli husus vardır. İlk olarak denetimin önceden belirlenen ölçütlere dayanıyor olmasıdır. Diğer bir husus yapılan denetimin standartlara uyularak yapılmasıdır. Son olarak üzerinde durulması gereken nokta da denetimin bağımsızlı̆̆ı ilkesi durumudur.

Denetim faaliyetlerinin güvenilirliği denetim raporunu kullanacak olanların denetçiye olan güvenleri oranında olacaktır. Denetçinin bağımsızlığına dair bir şüphe olması durumunda denetim faaliyetlerine olan güven de azalacaktır. Finansal tablo denetimi yapanların bağımsız denetçi talep etmelerinin altından yatan husus da budur. Denetçi kanıt toplama ve kanıtları değerlendirme esnasında ön yargıdan uzak, taraf olmayacak şekilde ve işinin uzmanı gibi denetimini tamamlamalıdır (Bayram, 2011: 4).

Bağımsız denetime ilişkin uygulamalarda denetim faaliyetleri üç ayrı şekilde sürdürülmektedir. Sürekli bağımsız denetim, sınırlı bağımsız denetim ve özel bağımsız denetim olarak bağımsız denetim faaliyetleri gerçekleştirilmektedir (Uyar, 2015: 1).

Herhangi bir süreye bağlı kalmaksızın faaliyetlerin yapıldığı yıl içerisinde denetçilerin belirlemiş olduğu periyotlarla yapılan denetim sürekli denetimdir. Bağımsız denetimin başladığı tarihten bitiş tarihine kadar yapılması gereken sürekli denetimde tüm denetim tekniklerinin kullanılması da mümkündür (Demirtaş, 2016: 775).

Bir işletmenin genel işlerini sınırlandırmak ve işletmenin kesintisiz çalışmalarını kolaylaştırmak amacıyla yapılan denetim türü de sınırlı denetimdir. Bu denetim türünde denetçi işlerini bir hesaba ve amaca ayırarak yapmaktadır. Sürekli denetimin aksine yılda birkaç kez yapılan sınırlı denetim türü denetçinin daha az zamanını alır (Netinbag, 2021: 1).

Özel bağımsız denetim, sermaye piyasası araçlarının halka arzı için Kurula başvuru sırasında veya birleşme, bölünme, devir ve tasfiye durumunda bulunan işletmelerce, bu amaçlarla herhangi bir tarih itibariyle düzenlenmiş finansal tabloların ilgili tebliğce belirlenmiş esaslara uygun olarak bağımsız denetime tabi tutulmasını ifade eder (SPK, 2013: 2). 


\section{Geleceğin Denetçisi}

İç Denetçiler Enstitüsü'ne (IIA) göre, "İç denetim, bir kuruluşun operasyonlarına değer katmak ve geliştirmek için tasarlanmış bağımsız, nesnel bir güvence ve danışmanlık faaliyeti” olarak tanımlanmıştır. İç denetim "risk yönetimi, kontrol ve yönetişim süreçlerinin etkinliğini değerlendirmek ve geliştirmek için sistematik, disiplinli bir yaklaşım getirerek bir kuruluşun hedeflerine ulaşmasına yardımcı olur." Geleceğin denetçisi terimi, hizmet verdiği kurum içinde bu vizyonu gerçeğe dönüştürmek için kesin ve stratejik adımlar atan işletmelerin iç denetimden sorumlu denetim yöneticisi veya denetimden sorumlu personeli kapsamaktadır.

Denetçi ve denetlenecek işletme arasında sözleşmeye dayalı bir düzenlemenin ilk kurulmasını takiben, bir denetim katılımı genellikle denetimin kapsamını ve hedeflerini sınırlayan bir risk değerlendirmesi ve bir denetim planının formülasyonu ile devam etmektedir. Daha sonra, denetçiler denetim kanıtlarını toplar ve analiz eder ve yönetim tarafından sağlanan bilgilerin güvenilirliğinin yanı sıra iç kontrolle ilgili görüşler oluşturmaktadır. Çalışma sonunda, denetçiler görüşlerini ifade eden resmi bir rapor sunarlar. Aslında, bu yaklaşım yirminci yüzyıl metodolojisini yansıtmaktadır, böylece bilgi toplama, bilgiyi işleme ve bilginin raporlanması ile ilgili yüksek maliyetler ile işletme açısından önem arz edecek zaman gecikmeleri işletmelere sağlanan katma değeri düşürmektedir.

Byrnes ve arkadaşları (2015) ABD'de denetim mesleğinin ne ölçüde ilerlediğini incelemek ve gelişmeye devam etmek ve topluma uzun vadeli değer sağlamak için gerekebilecek yörüngeyi belirlemek amacıyla yaptıkları çalışma sonucunda denetim faaliyetlerinin ekonomiye ayak uyduramadığ 1 ve geleneksel denetim yaklaşım ve tekniklerinin yetersiz olduğu belirtilmiştir. Dolayısıyla gelecekte denetçilerin denetim yaklaşımlarını şekillendireceğine ve denetçilerin odak noktalarının değişmesi gerektiğini belirtmiştir. Aynı şekilde Cangemi (2010), iş teknolojilerindeki son gelişmeler göz önüne alındığında, geriye dönük denetime devam eden vurgunun sadece modası geçmiş bir felsefe olduğunu savunmaktadır. Bunun yerine, gerçek zamanlı çözümlere ihtiyaç olduğuna inanmaktadır. Bu nedenle, geleceğin denetiminde daha gelişmiş programlara nihai olarak dikkat edilmeli ve daha yüksek bir güvence sağlaması konusunda adımlar altılması gerektiğini savunmaktadir.

Değişen ekonomik koşullar ve gelişen bilgi teknolojileri işletme paydaşlarının beklentilerinin değişmesine neden olmuştur. Dolayısıyla işletmeler faaliyetlerinde artı katma değer 
sağlamaya yönelik faaliyetlere önem vermeye başlamıştr. Bununla birlikte denetim faaliyetlerinin öneminin de artmasına neden olmuştur. Bununla birlikte denetimden sorumlu yönetici veya personellerin vizyonunu değişen durumlar çerçevesinde revize etmesi gerekmektedir. Geleceğin denetçisi olarak adlandırılan meslek mensupları işletmelerin belirlediği hedeflere ulaşmak için yapacağ sağlamasında yardımcı olacaktır. Dolayısıyla geleceğin denetçisi işletmenin "eli ayağı" olacaktır. Özellikle stratejik kararlar planlar veya programlar hazırlanırken geleceğin denetçisine büyük görevler düşmektedir. Geleceğin denetçisi verilen bu görevleri başarmak için kendisini her alanda geliştirmeli ve mesleki bilgisini revize etmelidir. Kısacası geleceğin denetçisi işletme faaliyetlerine artı katma değer sağlayabilecek yeni özelliklere sahip olmalıdır.

Cai (2021), Bir denetim görevini planlarken, denetçiler genellikle geçmişteki bir anlayışa ve eldeki mevcut bilgilere dayalı olarak risklerin ve endişelerin bir listesini kolayca derlemektedir. Oradan başlayarak denetçiler, denetçi şüpheciliğine uymak veya reddetmek için bir dizi analitik prosedür ve ölçütler oluşturur. Bununla birlikte, yalnızca geleneksel yaklaşıma güvenen denetçiler, başlangıçta denetçinin radarında olmayan riskleri veya anormallikleri bulmayı gözden kaçırabilirler. Dolayısıyla denetçilerin yeni düzene ayak uydurabilmeleri için bir zorunluluk oluşturmaktadır. Denetçiler özellikle bu yeni düzene, mesleki bilgi ve tecrübelerini revize ederek veya kendilerine yeni özellikler ekleyerek hizmet sağladığı işletmenin amaç ve hedeflerine ulaşmasına yardımcı olacaktır.

\subsection{Geleceğin Denetçisinin Özellikleri}

İşletmelerin iç denetiminden sorumlu yöneticilerin işletmelerin faaliyetlerinde değer katabilmesi için gerekli olan birtakım operasyonlara ihtiyaç duyulmaktadır (Protiviti, 2014). Bu operasyonlardan ilki işletmenin faaliyet birimleri, iş süreçleri ve paylaşılan işlevler konusunda tarafsız olacak şekilde konumlandırılmış olmalıdır. Ayrıca denetçiler yönetim kuruluna veya yönetim kurulu komitesine doğrudan raporlama yetkisine sahip olması gerekmektedir. İkinci olarak iç denetçilerin işletmelerin iş hedeflerini ve stratejisini anlamalı ve işletmenin hedeflerine ulaşmasına ve stratejisini başarılı bir şekilde yürütmesine engel oluşturan riskleri belirlerken stratejik düşünmelidir.

Üçüncü olarak risk değerlendirmede, denetim kapsamını genişletmede, kritik iç kontrolleri otomatikleştirmede, sorunları takip etmede, istisna raporları sağlamada ve ortaya çıkan riskler ve 
süreç ve kontrol performansı hakkında anlamlı bilgiler elde etmek ve veri madenciliği ve analizinde verimlilik elde etmek için teknoloji kullanımını en üst düzeye çıkarmalıdır. Son olarak işletmenin kritik risklerini ele alan yönetişim, risk yönetimi ve iç kontrol süreçlerinin tasarım ve işletim etkinliğini değerlendirme ve sorgulama yetkisine sahip olmak; geleceğin denetçisi de bu süreçleri güçlendirmek için tavsiyelerde bulunarak ve uygun yönetici ve direktörleri açık konular hakkında bilgilendirerek değer yaratacaktır.

İç denetimin faaliyetlerinin kapsamının genişlemesi, denetim faaliyetlerini gerçekleştirecek denetim personelinin de odak noktalarının kapsamını genişletmektedir. Dolayısıyla denetim personeli, hizmet verdiği kurumun faaliyetlerinde günceli yakalayan, bilgi teknolojilerinden yararlanan, denetim faaliyetleri ile katma değer sağlayacak kesin adımlar atan kişiler olarak görülmektedir. Geleceğin denetçi olarak adlandırılan denetim personelinin öncelikle işletmelerin faaliyet birimleri, iş süreçleri ve paylaşılan işlevler konusunda tarafsız olunacak şekilde konumlandırılmalıdır. Bununla birlikte denetim personelinin işletmelerin yönetim kurullarına veya yönetim kurulu komitesine doğrudan raporlama yetkisine sahip olması gerekmektedir. Dolayısıyla denetim personelinin üst yönetim ile sürekli olarak bilgi alışverişinin sağlanmasına ve direkt olarak iş operasyonlarına ihtiyaç doğrultusunda müdahale imkanı sağlanmış olacaktır.

\subsection{Geleceğin Denetçisinin Katma Değeri}

Denetçiler sadece denetim komitesi veya diğer raporlama kuruluşu için işlerini yaparak değer katmaktadırlar. Denetim işlevi bir yönetişim denetimi görevini yerine getirmenin yanı sıra kuruluşun genel kontrol sistemlerini güçlendirerek ve varlık düzeyi, endüstri ve iş kolu risklerini ele almayı amaçlayan kritik denetimlerin güvence gözden geçirmelerini gerçekleştirerek önemli bir rol oynamaktadır. Bu incelemeler, yönetim kuruluna, dış denetçilere ve en önemlisi denetim komitesine, kurum içindeki kilit kontrollerin uygun şekilde tasarlandığını, etkin ve verimli bir şekilde çalıştığını ve paydaşları korumak için çalıştığını garanti etmektedir. Bu tür bir güvence hizmetleri denetçilerin parasal olarak ölçmesi mümkün olmamakla birlikte katma değerli faaliyetler olarak kabul edilmektedir.

İç denetçiler risk değerlendirme ve iç kontrol uzmanlarıdır. Bu alanlardaki uzmanlıkları, yönetimin işletmeye yönelik riskleri analiz etmesine yardımcı olmalarını ve bu riskleri azaltmak için kontroller tasarlamalarını sağlamaktadır. Denetçiler, denetimler gerçekleştirerek, sorunları araştırarak ve hizmet sağladığı işletmelere uygun en iyi uygulamaları kararlaştırarak iç kontrol 
tasarımını yapmaktadır. Bu faaliyetler aynı zamanda işletmelere katma değer oluşturmada yardımcı olmaktadir.

Geleceğin denetçisinin işletmelere değer katabileceği yollar şu şekilde belirlenmiştir. Denetim planlarını oluştururken ve risk analizleri yaparken daha stratejik düşünmek, mevcut ve muhtemel riskler için ilgililere erken uyarılar yapmak, risk yönetiminin çalışmasını sağlayan savunma hatlarını güçlendirmek, operasyonlar, uyumluluk ve finansal olmayan raporlama sorunlarına odaklanmayı genişletmek, kuruluş genelinde karar verme için bilgileri geliştirmek, bozulan risk kültürünün belirtilerini izlemek, yönetim ve yönetim kurulu ile etkin iletişim yoluyla güvenceye verilen önemi genişletmek, risk ve uyumluluğu yönetmeye odaklanan diğer bağımsız işlevlerle daha etkin bir şekilde işbirliği yapmak, kaldıraç teknolojisi özellikli denetim yapmak, otomatik kontrollerin kullanımı da dahil olmak üzere kontrol yapısını iyileştirmek, uyumluluk yönetimini iyileştirme ve kolaylaştırma konusunda tavsiyelerde bulunmak ve dolandırıcılık konusunda daha dikkatli olmaktır (Protiviti, 2014).

Denetçiler hizmet sunduğu işletmelerde hem denetim planlaması yaparken hem de muhtemel risklerin analizlerini yaparken geleneksel yöntemlerin ilerisinde işletmelerin amaçları doğrultusunda daha stratejik kararlar üzerine yoğunlaşması işletmelerin sürekliliği konusunda önem arz etmektedir. Geleneksel yöntemler kullanarak oluşturulan denetim planlaması ve risk analizleri daha çok mevcut durum üzerine veya muhtemel riskler üzerine çalışmalar doğrultusunda yapılmaktadır. Aksine geleceğin denetçisinin sadece mevcut durumlar için değil hizmet sunduğu işletmenin daha stratejik kararlar almasına imkân tanıyacak faaliyetleri gerçekleştirebilecek planlama ve risk analizleri üzerinde çalışmalıdır.

İç Denetçiler Enstitüsü (IIA) İç Denetim Vakfı (IAF), (2021) Deloitte ile işbirliği içinde, iç denetçilerin temel bilgi alanlarında güçlü yetkinliğe sahip olduğunu, aynı zamanda yenilikçi ve gelişmekte olan risk alanlarında önemli firsatlara ve ek kaynaklara kritik bir ihtiyaç duyduğunu doğrulayan yeni bir çalışmanın sonuçlarını yayınlanmıştır. Sonuçlar, ileriye dönük olarak, iç denetim işlevlerinin ve kuruluşların riskleri ele almak ve şirketlere önemli dönüşüm konusunda tavsiyelerde bulunma firsatlarını en üst düzeye çıkarmak için kaynak tahsisini ve yetenek geliştirmelerini yeniden düşünmeleri gerekebileceğini göstermektedir. Genel olarak, ankete katılan iç denetçiler, rolleriyle ilgili temel bilgi alanlarında oldukça gelişmiş yetkinliklere sahip olduklarını 
bildirmektedir. Ancak katılımcılar, iç denetimde yenilikçi teknolojilerin kullanımına daha fazla odaklanmaya kritik bir ihtiyaç olduğunu da söylemiştir.

Geleceğin denetçisi faaliyetlerde stratejik düşünmenin yanı sıra mevcut ve muhtemel riskler için yönetim kurulu veya üst yönetime erken uyarılarda bulunması gerekmektedir. Mevcut operasyonların devamının sağlanması, işletme faaliyetlerinin sürdürülebilirliği veya rekabetin sağlanması konusunda oluşan veya oluşması muhtemel riskler için erkenden alınan tedbirler etkili olacaktır. Burada geleceğin denetçisine büyük rol düşmektedir. Ayrıca denetçilerin ileri görüşlülüğü ve mesleki tecrübesi hizmet sunduğu işletmeye artı değer katacaktır. PWC (2019) tarafından yapılmış bir çalışmada çoğu katılımcının bir şirketin karşılaştığı risklerle ilgili uyarı işaretlerinin şirketin faaliyet raporunda daha şeffaf ve daha kolay yorumlanabilir hale getirilmelidir ve genişletilmiş denetçi raporunda denetçi tarafından işaretlenmesinin gerektiği belirtilmiştir. Dolayısıyla denetçilerin denetim raporlarında finansal bilgilerdeki uyarıcı işaretlerin daha belirgin bir şekilde yansıtılması geleceğin denetçisinin önemli görevleri arasında gösterilmektedir.

Bilgisayarlı ve genellikle dış kaynaklı olacak gelecekteki sistemlerin güvencesinde çok önemli bir adım olan iç kontrollerin denetçi değerlendirmesine odaklanmaktadır. Muhasebe mesleği artık denetimi daha da yüksek otomasyon seviyesine çıkarmak için bir firsatla karşı karşıyadır. Muhasebecilerin, geleceğin denetim taahhütlerine göre tercih ettikleri profesyoneller olmaya devam etmeleri için gelecekteki denetimin benimsenmesine ve uygulanmasına öncülük etmeleri zorunludur.

Deloitte (2021), denetim süreci, bilgisayar destekli denetim araçlarının benimsenmesinden bu yana geçen 30 yılda temelde değişmeden kalmıştır. Sürekli teknolojik ilerleme ve bilgi akış1, finansal raporlama için yeni bir ortam yaratarak, bu bilgi bolluğunu daha erişilebilir ve kullanımı kolay hale getirmektedir. Ayrıca, makine öğrenimi, bilişsel bilgi işlem ve daha pek çok farklı teknolojik alandaki ilerleme, denetim sürecini ve denetçinin işini önemli ölçüde etkilemekte ve geliştirmektedir. Böylece denetim kalitesini sürekli iyileştirme ve yapısal riskleri azaltma konusunda muazzam bir potansiyel ortaya çıkmaktadır. Ayrıca, yeni denetim süreçlerinden kolaylıkla elde edilebilecek, kuruluşun finansal durumu ve performansıyla ilgili daha derin ve daha alakalı anlayışlara önemli bir ihtiyaç vardır. Ancak ilerlemenin her zaman bir maliyeti vardır. Veri güvenliği, şeffaflık ve hatta denetçi bağımsızlığı gibi zorluklar ve engeller her zaman söz konusudur. Klasik muhasebeci bu yenidünya için gerekli becerilere sahip değildir. Bu nedenle, 
yukarıda açıklanan sürece, denetçilerin tarihsel becerilerinin dışında kalan alanlarda yeni mesleki eğitim eşlik etmelidir. Denetim uygulayıcılarının siber adli tıp, risk yönetimi, analitik ve bilgi teknolojileri gibi tamamen yeni bir dizi beceri ve çalışma metodolojisini benimsemeleri gerekecektir.

Denetçiler bir şirketi değerlendirdiğinde, odak genellikle işletmenin arkasındaki verilere odaklanır ve bu veriler daha sonra gözlemleri formüle etmek ve sonuç çıkarmak için kullanılır. Geçmişteki denetimlerde, teknoloji sınırlamaları denetçileri yalnızca seçilen işlemleri gözden geçirmeye zorlamakta ve bu da onlara sonuç çıkarmak için bir işletmenin sınırlı bir görünümünü sağlamaktadır. Denetçiler, denetime ve müşterilerine gerçek değer sağlama yeteneklerini daha da sınırlayan entegre bir görünüme sahip olmadan geçmiş verilere odaklanmaktadır. Bununla birlikte, denetçiler artık sınırlı miktarda verinin üzerine çıkma ve gözlemleri kapsam dışı etme yeteneğini kazanmaları gerekmektedir. Genişletilmiş gerçek zamanlı iç ve dış görüşe sahip olma özelliği ile denetçiler artık bütünsel olarak düşünebilir ve şirketlerinde inovasyonu teşvik edebilir. Bulut tabanlı denetim çözümleri, sürekli denetim, gerçek zamanlı risk/uyumluluk izleme, gerçek zamanlı uygulama izleme, bilişsel destekli karar verme ve sağlam veri analizi, mesleğin şu anda harekete geçmesi veya eskimesi gereken yeniliklerden sadece birkaçıdır (Anderson, 2017: 5).

Forbes Insights ve KPMG (2017) tarafindan yapılan çalışmaya göre, denetçilerin çeşitli konularda daha ileriye dönük olmaları gerektiğini söylemektedir. Ankete katılanların yaklaşık yarısı (\%45), denetçilerin daha büyük örnekleri analiz etmesi ve daha derin bir analiz yapması çağrısında bulunmanın yanı sıra, denetimin kapsamının dolandırıcılık riskleri ve kuruluşun risk yönetimi süreçleri, BT sistemlerine ilişkin daha iyi odak ve analizler ve paydaşlar tarafından değer verilen diğer konuları içerecek şekilde genişletilmesi gerektiğini belirtmiş̧tir.

\section{Sonuç}

Gelecekteki denetime doğru ilerlerken, verilerin, denetimlerin ve işlemlerin ne ölçüde otomatikleştirildiği göz önünde bulundurulmalıdır. Denetim ürününü şu anda yaptıklarının ötesine genişletmek için güçlü çağrılar olmasa da, denetçilerin finansal tablo kullanıcılarının değişen ihtiyaçlarına karşı uyanık olmaları ve kullanıcıları karşılamak için denetim ürününü, kapsamını ve gereken güvence düzeylerini yenilikçi bir şekilde geliştirmeleri gerekmektedir.

Teknoloji, günümüzün finansal raporlama ortamında önemli bir rol oynamaktadır. Mesleğimizin denetim kalitesini korumasına yardımcı olmakta ve yönetimin 
belgeleri hazırlamak için harcaması gereken zamanı azaltmaktadır. İnovasyon, denetçilerin ve firmalarının sürekli başarısı için çok önemlidir. Günümüzde büyük veri ve veri analitiği, denetçilerin içgörü sağlamak için kullanabileceği en güçlü donelerdir. Aslında, içgörüler olmadan, yenilik olamaz. Gelişen teknolojilerle birlikte gizlilik ve güvenlik sorunu ortaya çıkıyor. Tüm yeniliklerin finansal raporlama ekosistemi için iyileştirmelerle sonuçlanması kritik öneme sahiptir ve bilgi toplamak için tüm teknolojilerin güvenli ve etkili bir şekilde kullanılmasını sağlamak denetim mesleğinin görevidir. Ayrıca denetçiler finansal sonuçların ötesine geçen performans göstergelerini de dikkate alarak değerlendirmelerde bulunmalıdır.

Geleceğin denetçisi geleneksel yaklaşım ve yöntemlere ek olarak gelişen bilgi teknolojilerine adapte olan yaklaşım ve yöntemleri uygulaması hizmet sağladığı işletmeye artı katma değer sağlamasına yardımcı olacaktır. Özellikle bulut tabanlı denetim çözümleri, sürekli denetim, gerçek zamanlı risk/uyumluluk izleme, stratejik risklere daha fazla önem verme, gerçek zamanlı uygulama izleme, bilişsel destekli karar verme ve sağlam veri analizi konularında hâkimiyet sağlamaları gerekmektedir. Bununla birlikte katma değer sağlayan danışmalık faaliyetleri, üst yönetim başta olmak üzere işletme genelinde etkili ve proaktif iletişim ağının sağlanması, risk yönetimi ve iç kontrolün etkin bir şekilde işlemesini sağlamak için bir savunma hattı perspektifinin kullanılması ve özellikle önemli konuları zamanında üst yönetimin ve yönetim kurulunun dikkatine sunmak amacıyla yönetimden daha proaktif yetkiler alınması katma değer sağlayıcı faaliyetlerin oluşmasına imkân tanıyacaktır.

Geleceğin denetçisi, hizmet sağladığı kuruluşun iş hedefleri ve stratejilerini detaylı bir şekilde anlamalı ve kuruluşun hedeflerine ulaşmasına ve stratejisini başarılı bir şekilde yürütmesine engel oluşturan riskleri belirlerken stratejik düşünmelidir. Denetim personeli hizmet sağladığ1 kuruluşun kritik risklerini ele alan yönetişim, risk yönetimi ve iç kontrol süreçlerinin tasarım ve işletim etkinliğini değerlendirme ve sorgulama yetkisine sahip olmalıdır. Dolayısıyla denetim personeli bu süreçleri güçlendirmek için tavsiyelerde bulunarak ve uygun yönetici ve direktörleri açık konular hakkında bilgilendirerek katma değer yaratacaktır. Ayrıca denetim personeli risk yönetimi ve iç kontrolün etkin bir şekilde işlemesini sağlamak için bir savunma hattı perspektifi kullanmalıdır. Yönetim kurulu ve üst yönetimin anlayabileceği bir güvence perspektifi sağlanmalı ve riske dayalı bir denetim planının oluşturulmasıyla kuruluşa sağlayacağı katma değer belirtilmelidir. Ayrıca risk değerlendirmede, denetim kapsamını genişletmede, kritik iç kontrolleri otomatikleştirmede, sorunları takip etmede, istisna raporları sağlamada ve ortaya çıkan riskler ve 
süreç ve kontrol performansı hakkında anlamlı bilgiler elde etmek için veri madenciliği ve analizinde verimlilik elde etmek için teknoloji kullanımına gerekli önem verilmelidir. Bununla birlikte riskli ve önemli konuları üst yönetimin veya yönetim kurulunun dikkatine sunmakta amacıyla denetim personeline sunulan yetkileri proaktif olarak kullanılması işletmelerde katma değer yaratacaktır. Kısacası geleceğin denetçileri hem işletme yönetimi hem de işletme bilgi kullanıcıları arasında en uygun ve doğru dengeyi sağlamada kilit rolü üstlenmelidir.

\section{Kaynakça}

Akyüz, F., \& Kestane, A. (2020). Yasal Mevzuat Işığında Denetçi Bağımsızlığı. IBAD Sosyal Bilimler Dergisi(6), 184-203.

Anderson, 2017. https://tax.thomsonreuters.com/site/wp-content/private/pdf/ checkpoint/whitepapers/Checkpoint-Al-Anderson-Whitepaper.pdf adresinden alınd1.

Aqel, S. (2014). Independent Auditor's Report: Messages Conveyed and Implications. Acta Universitatis Danubius. Economica, 10(5), 5-17.

Bayram, G. (2011). Bă̆ımsız Denetim Süreçleri. Deloitte.

Bozkurt, N. (2015). Muhasebe Denetimi (7 b.). İstanbul: Alfa.

Byrnes, P.E., Al-Awadhi, A., Gullvist, B., Brown-Liburd, H., Teeter, R., Warren, J.D. ve Vasarhelyi, M. (2015). Evolution of Auditing: From the Traditional Approach to the Future Audit. Audit Analytics and Continuous Audit: Looking Toward the Future. American Institute of Certified Public Accountants, Inc. New York. ss: 71-85.

Cai, M., (2021). Erişim: https://iaonline.theiia.org/blogs/Your-Voices/2021/Pages/On-theFrontlines -Data-driven-vs-Data-informed.aspx adresinden alınd1.

Cangemi, M. April, 2010. "Internal Audit's Role in Continuous Monitoring," The EDP Audit, Control, and Security Newsletter 41 (4).

Deloitte, (2021). Erişim: https://www2.deloitte.com/il/en/pages/innovation/article/auditor_ofthe future.html. adresinden alınd1.

Demir, M., Ülker, Y., \& Arslan, Ö. (2018). İç Kontrol, İç Denetim ve Bağımsız Denetim İlişkisi. Van Yüzüncü Yıl İktisadi ve İdari Bilimler Fakültesi Dergisi, 3(5), 82-104.

Demirtaş Aydoğan, S. (2016). Türkiye'de Bağımsız Denetimin Yeni Türk Ticaret Kanunu Çerçevesinde Değerlendirilmesi. Uluslararası Yönetim İktisat ve İşletme Dergisi,(ICAFR 16 Özel Sayıs1 ), 771-785.

Franklin, B. (2017, 10 08). What is Auditing - Auditing Definition, Introduction and Meaning. Kasim 18, 2021 tarihinde RCV Academy: https://www.rcvacademy.com/auditingintroduction/ adresinden alınd 1 
Gökoğlan, K. (2021). Bağımsız Denetçilik Mesleği Üzerine Bir Araştırma. Van Yüzüncü Yıl Üniversitesi IIBBF Dergisi, 6(11) 66-78.

Hatunoğlu, Z., \& Koca, N. (2020). Bağımsız Denetçinin Eğitim Seviyesi ve Mesleki Tecrübesine Göre Mesleki Bağlılık ve Denetimde Kalite Alg1 Düzeyi. Kahramanmaraş Sütçü Imam Üniversitesi Sosyal Bilimler Dergisi, 17(2), 1118-1134.

Hayes, R., Dassen, R., Schilder, A., \& Wallage, P. (2005). Prınciples of Auditıng An Introduction to International Standards on Auditing (Second Edition b.). Harlow: Pearson Edication.

ICSI. (2014). Fundamentals of Accounting and Auditing. New Delhi: The Institute of Company Secretaries of India.

IIA, 2021. https://na.theiia.org/news/Pages/Internal-Audit-Foundation-and-Deloitte-ReleaseGlobal-Research-Study-Assessing-Internal-Audit-Competency.aspx

KPMG, 2017. https://assets.kpmg/content/dam/kpmg/us/pdf/2017/03/us-audit-2025-finalreport.pdf. adresinden alınd1.

Netinbag. (2021). Sinırl Denetim Nedir? Kasım 26, 2021 tarihinde Netinbag: https://www.netinbag.com/tr/finance/what-is-a-limited-audit.html adresinden alınd

Öztürkçü A., A., \& Bilen, A. (2018). Denetim Kalitesi ve Göstergeleri. Van Yüzüncü Yıl Üniversitesi Sosyal Bilimler Enstitüsü Dergisi(40), 227-256.

Protiviti, 2014. The Future Auditor: The Chief Audit Executive's Endgame," Issue 6 of Volume 5 of Protiviti's The Bulletin, April 2014, available at www.protiviti.com.

PWC, (2019). https://www.pwc.co.uk/who-we-are/future-of-audit/pwc-future-of-audit-reportjuly-2019.pdf adresinden alınd1.

Saxunova, D. (2017). Accountant and Auditor and Their Skills and Compentences in Contemporary Environment. Social No-Ekonomicka Revue(2), 43-52.

SPK. (2013). Sermaye Piyasasında Bă̆ımsız Denetim Standartları Hakkında Tebliğ (Seri: X, No: 22). Kasim 24, 2021 tarihinde Sermaye Piyasası Kurulu: https://spk.gov.tr/Sayfa/Dosya/590 adresinden alındı

Tez, B. (2021). Bağımsız Denetim Standartları Kapsamında Bağımsız Denetim ve İç Kontrolün Etkileşimi. Muhasebe ve Finansman Dergisi(89), 113-132.

Uyar, S. (2015). Denetim Standartlarına Göre Sınırlı Bağımsız Denetim (Finansal Tabloların Gözden Geçirilmesi). Mali Çözüm Dergisi, 25(130), 15-39. 